this expected decrease in life-span will be due to leukæmia, which is known to affect over-exposed individuals with more than average frequency. The question whether diagnostic X-radiation during pregnancy increases the incidence of leukrmia in the children cannot be decided on the available evidence. Neither can it be decided whether there is a lower threshold to the production of tumours and leukæmia by irradiation, but the sub-committee dealing with hæmatological effects thinks it prudent to assume that for leukæmia no threshold exists. Mammalian embryos are readily affected by low doses of ionizing radiation. One of the most sensitive known indicators of chronic biological damage is the gradual reduction in number, motility and viability of sperm, resulting from small chronic radiation over-exposure. In dogs, effects on sperm have been observed at chronic doserates of only ten times the maximum permissible value for human occupational exposure.
Considerable space is devoted to recommendations for future research, especially in the field of genetics. The need for basic research is stressed, and the relevance of mutation research on all forms of life, including bacteria and viruses, is pointed out. On the other hand, attention is directed to problems that arise in human populations and have no counterpart in animal societies. Thus: "human society depends upon a diversity of performance among its members and on very high mental qualities among a few of them. A human civilization might collapse by becoming qualitatively inadequate, even though reproductive selection of certain kinds were acting at high intensity and the number of individuals in the population remained at a level that was previously optimal". These sentences have an obvious relevance to the questions discussed in the leading article "Evolution of Mankind" in Nature of February 13.

C. Aumrbach

\title{
MODERNIZATION OF THE STOCKHOLM CYCLOTRON
}

\begin{abstract}
TN'two papers published during 1952, H. Atterling and $\mathrm{G}$. Lindström described the initial performance of the fixed frequency $225-\mathrm{cm}$. cyclotron at the Nobel Institute of Physics, Stockholm (Arkiv for Fysik, 4, $559 ; 1952$, and Nature, 169,$432 ; 1952)$. A more detailed description of the machine, which has operated reliably and stably for several years producing internal beams of protons, deuterons, alphaparticles and heavy ions (carbon, nitrogen, oxygen and neon ions), is given in two recent articles in Arkiv for Fysik $(15,483$ and $531 ; 1959)$. The oscillator-frequency used recently is $8.1 \mathrm{Mc} . / \mathrm{s}$. and with this frequency the machine accelerates ions to a nominal energy of about $11 \mathrm{MeV}$. per nucleon at a radius of $90 \mathrm{~cm}$. Internal beam currents of approximately $300 \mu \mathrm{amp}$. of $22-\mathrm{MeV}$. deuterons are obtained.

In March 1958, the cyclotron was shut down and taken to pieces for remodelling. Previously it had been run exclusively with internal beams, but when the dees were designed provision was made for the subsequent mounting of an internal d.c.-deflector in one of the dees and during the reassembly of the dees the deflector is being installed.
\end{abstract}

The machine is housed in an underground hall, resting directly on rock and surrounded on all sides by rock, clay and earth. On the top it is shielded by a water pond two metres deep. The control room is in a three-storey building above ground, and the connexion between the building and the cyclotron hall is via a stairway or a lift to the bottom of a shaft from which a corridor leads to the hall. A removable $150-\mathrm{cm}$. concrete thick wall partly closes the corridor, leaving an opening $140 \mathrm{~cm}$. broad which can be closed by a concrete door weighing 35 tons. The first article contains full details together with drawings and photographs of the building; the magnet; the radiofrequency tank and dee systems; and the ionsource of the cyclotron. In the second article the techniques used in the work on heavy-ion acceleration in the cyclotron together with some results of the investigation of the energy-distribution for ${ }^{12} \mathrm{C}^{4+}$ ions are outlined. It is shown that the distribution contains a low-energy component in addition to the higher-energy peak of the ions. Other applications of the accelerated heavy-ions, in particular for the production of transuranium elements, are briefly mentioned.

\section{DAILY FOOD CONSUMPTION BY SOUTH AFRICAN UNIVERSITY STUDENTS}

T has been the practice of the Department of 1 Physiology of the University of the Witwatersrand to request students, as part of their physiological training, to keep a daily record of their food consumption over a defined period of time. The records from one year's class form the basis of a preliminary report by Sonia $\mathrm{E}$. Walker ; but it is hoped that data accumulating over several years will afterwards be analysed, and will give some indication of the diet. ary trends in this student section of the community (South African J. Med. Sci., 24, December, 1959).

The food consumption-levels of the students investigated are similar to those reported from other parts of the world. In a survey of dietary levels of households in the United States, the average consumption per person per day was found to be $2,760-3,260$ calories, 87-115 gm. protein and 133-161 gm. fat. The share of total calories derived from carbohydrate was 43 per cent, from protein 13 per cent, and, from fat, 44 per cent. A more recent report based on the estimation of apparent civilian consumption per capita per day in the United States gives mean daily intakes of 3,160 cal., $96 \mathrm{gm}$. protein, $378 \mathrm{gm}$. carbohydrate and $144 \mathrm{gm}$. fat. In the United Kingdom a similar estimation of food consumption per head of civilian population per day gave 2,890 cal., $380 \mathrm{gm}$. carbohydrate, $112 \mathrm{gm}$. fat, and $90 \mathrm{gm}$. protein. 